\title{
PREVALENCE OF HUMAN PAPILLOMA VIRUS AND ITS ASSOCIATED RISK FACTORS IN WOMEN WITH ABNORMAL CYTOLOGY AT A TERTIARY CARE HOSPITAL OF NORTH INDIA
}

\author{
Bhawna1, Kanwardeep Singh ${ }^{2}$, Loveena Oberoi³, Pusha Devi ${ }^{4}$ \\ 1 Junior Resident, Department of Microbiology, GMC, Amritsar. \\ ${ }^{2}$ Associate Professor, Department of Microbiology, GMC, Amritsar. \\ ${ }^{3}$ Professor, Department of Microbiology, GMC, Amritsar. \\ ${ }^{4}$ Professor and HOD, Department of Microbiology, GMC, Amritsar.
}

\section{BACKGROUND}

ABSTRACT

Cervical cancer is the fourth most common cancer worldwide. High-risk Human Papilloma Virus (HPV) infection is an important event in the progression of cervical cancer. The most common HPV types associated with pre-invasive and invasive cervical lesions are HPV 16, 18, 31, 33 and 45. As anogenital HPV infection is transmitted by sexual intercourse, sexual behaviour patterns among women and their partners often dictate women's risk for HPV infection and acquisition.

Aim of this study was to know the prevalence of HPV and its associated risk factors in women with abnormal cytology.

\section{MATERIALS AND METHODS}

The samples were processed for DNA extraction and finally amplification of this DNA was done with the help of PCR system using specific primers for the detection of HPV DNA.

Study Design- We performed a prospective observational study on 50 clinical samples of cervical scrapings from women with abnormal cytology.

\section{RESULTS}

In our study, prevalence of HPV came out to be 28 percentage. Early age at marriage, multiple sexual partners, use of OCPs, multiparity were found to be significant risk factors for HPV infection.

\section{CONCLUSION}

Our study concluded that younger age at marriage, multiple sexual partners, multiparity, use of OCPs are the most important risk factors for the acquisition of HPV infection.

\section{KEYWORDS}

Cervical Cancer, HPV, Risk Factors.

HOW TO CITE THIS ARTICLE: Bhawna, Singh K, Oberoi L, et al. Prevalence of human papilloma virus and its associated risk factors in women with abnormal cytology at a tertiary care hospital of North India. J. Evolution Med. Dent. Sci. 2017;6(89):61726174, DOI: $10.14260 /$ jemds/2017/1341

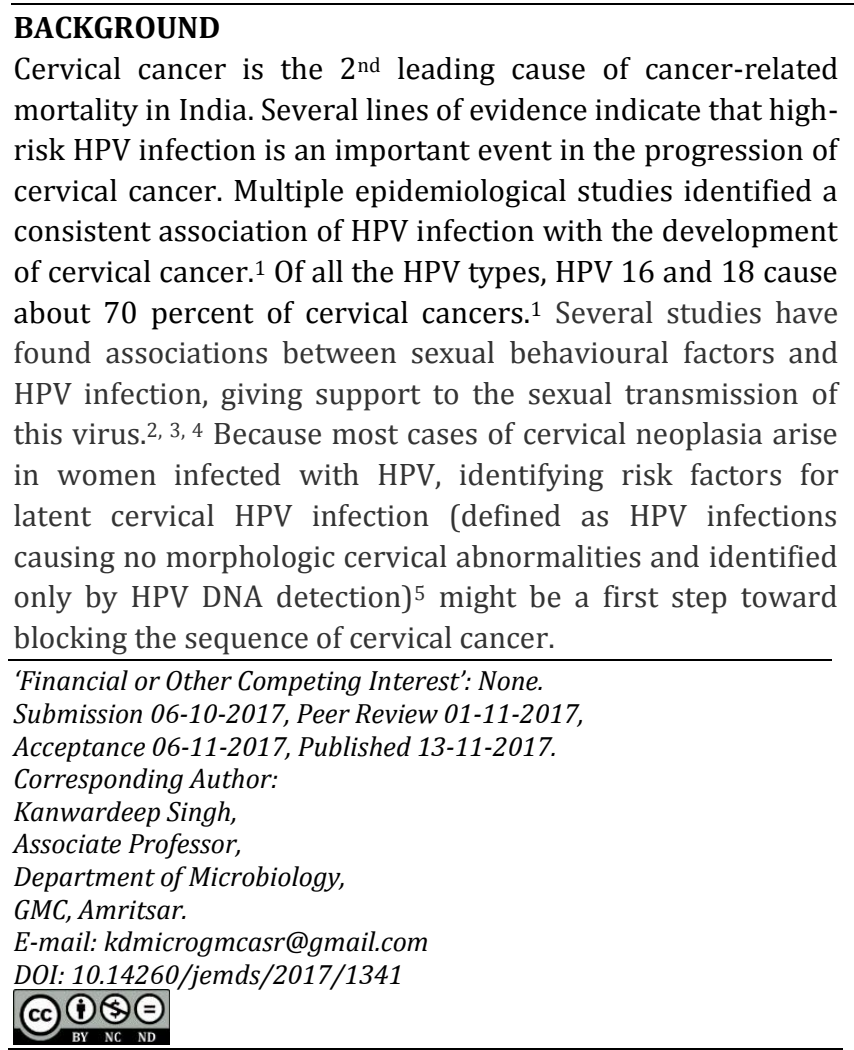

This study provided an opportunity to investigate the determinants of HPV DNA along with its prevalence in women with abnormal cytology in relation to demographic, sexual and reproductive factors.

\section{MATERIALS AND METHODS \\ Study Design}

A prospective observational study was conducted in the Virology section of Department of Microbiology, Government Medical College, Amritsar from $1^{\text {st }}$ January 2016 to $30^{\text {th }}$ June 2017 after taking approval from Institutional Ethical Committee. The study comprised of samples of cervical scrapings from the women with abnormal cytology attending Obstetrics and Gynaecology OPD/IPD of Bebe Nanki Mother \& Child Care Centre, Guru Nanak Dev Hospital who were ready to give their samples for research purpose. Patients who didn't give consent \& Pregnant Female patients were excluded in this study. So we were able to get 50 samples from the women with abnormal cytology who volunteered during the study period. All the participants answered a complete standardised questionnaire concerning age, age at marriage, age at first sexual intercourse, number of lifetime sexual partners, oral contraceptive use and number of pregnancies. 


\section{Sample Collection}

50 clinical samples in the form of cervical scrapings were obtained using Ayre's spatula/Cytobrush from women with abnormal cytology. The collected samples were transported in suitable transport medium (Phosphate Buffer Saline) to Virology laboratory. The samples were processed on the same day, in case of delay, collected samples were stored at $80^{\circ} \mathrm{C}$.

\section{Sample Processing}

\section{DNA extraction}

By spin column technique.

Each sample was processed for DNA extraction according to the instructions manual given along the QIAamp DNA mini kit 51304 by Qiagen.

2. Polymerase Chain Reaction (PCR)

Amplification of DNA is done with the help of specific primers (GP5+/GP6+), dNTPs, Taq Polymerase for the detection of HPV DNA.

\begin{tabular}{|c|c|c|}
\hline HPV Genotype & Amplicon (bp) & Sequence (5'-3') \\
\hline GP 5+ & 140 & $\begin{array}{c}\text { FP- TTT GTT ACT GTG } \\
\text { GTA GAT AC }\end{array}$ \\
\hline GP 6+ & 140 & $\begin{array}{c}\text { RP- GAA AAA TAA ACT } \\
\text { GTA AAT CA }\end{array}$ \\
\hline
\end{tabular}

\begin{tabular}{|c|c|}
\hline Content & Volume $(\mu \mathrm{L})$ \\
\hline Nuclease-free water & 6 \\
\hline Taq Buffer & 8 \\
\hline dNTPs & 3 \\
\hline GP5+ & 3 \\
\hline GP6+ & 3 \\
\hline Taq Polymerase & 2 \\
\hline Total & 25 \\
\hline
\end{tabular}

Template DNA $=5 \mu \mathrm{L}$

\begin{tabular}{|c|c|c|}
\hline $\begin{array}{c}\text { Initial } \\
\text { Denaturation }\end{array}$ & $\mathbf{5}$ Minutes & $\mathbf{9 5}^{\circ} \mathrm{C}$ \\
\hline 3-step cycling & & \\
Denaturation & 45 seconds & $94^{\circ} \mathrm{C}$ \\
Annealing & 45 seconds & $55^{\circ} \mathrm{C}$ \\
Extension & 45 seconds & $72^{\circ} \mathrm{C}$ \\
No. of cycles & 35 & \\
\hline Final extension & 3 minutes & $72^{\circ} \mathrm{C}$ \\
\hline \multicolumn{2}{|c|}{ Holding } & $4^{\circ} \mathrm{C}$ \\
\hline \multicolumn{2}{|c|}{ Table 2. Cycling Conditions for Amplification } \\
\hline
\end{tabular}

\section{Analysis of Amplified Products}

Amplified products were subjected to gel electrophoresis and analysed on Gel Documentation system.

\section{Statistical Analysis}

Chi square test was performed to study the associations between various risk factors and HPV infection. This test was considered statistically significant at $5 \%$ level ( $\mathrm{p}$ value < 0.05).
RESULTS

Out of total 50 patients, $28 \%$ were positive \& $72 \%$ were negative for HPV.

\begin{tabular}{|c|c|c|}
\hline HPV DNA & $\begin{array}{c}\text { Number of } \\
\text { Patients }\end{array}$ & $\begin{array}{c}\text { Percentage } \\
(\%)\end{array}$ \\
\hline Positive & 14 & 28 \\
\hline Negative & 36 & 72 \\
\hline Total & $\mathbf{5 0}$ & $\mathbf{1 0 0}$ \\
\hline \multicolumn{2}{|c|}{ Table 3. Distribution of Patients According to } \\
Presence of HPV DNA (n=50)
\end{tabular}

In this study, we further tried to determine the association of different factors with HPV infection. Out of the total 14 patients positive for HPV, $8(57 \%)$ belonged to the age group of $<30$ years, $4(28.6 \%)$ belonged to age group $>40$ years and $2(14 \%)$ to $31-40$ years of age group. This relation between HPV and age of the patient was found to be statistically significant $(\mathrm{p}=0.0295)$.

Of the total positive patients, $9(64 \%)$ got married in age group of $18-25$ years, $5(35.7 \%)$ in 26-30 years of age and none in age group 31-35 years $(\mathrm{p}=0.0016)$. Among the HPV infected patients, $8(57 \%)$ were of para $3,5(35 \%)$ were of para 2 and $1(7 \%)$ was of para $1 .(p=0.0133)$.

Of the total 14 patients positive for HPV DNA, $2(14 \%)$ had multiple sexual partners and rest 12 (85.7\%) had single partner. $(p=0.0206)$. Out of the positive cases, $7(50 \%)$ had bacterial vaginosis, $4(28.5 \%)$ had trichomoniasis, $1(7 \%)$ HSV, followed by no other STI in $2(14 \%)$ patients. Among the HPV positive cases, $7(50 \%)$ of them were using OCPs, 3 (21.4\%) Cu T \& $2(14.2 \%)$ tubectomy, Only 1 (7\%) was using condom and coitus interruptus each (Table 5) ( $p=0.0005)$.

\begin{tabular}{|c|c|c|}
\hline $\begin{array}{c}\text { Demographic } \\
\text { Characteristics }\end{array}$ & $\begin{array}{c}\text { Total No. of } \\
\text { Females }\end{array}$ & $\begin{array}{c}\text { No. of Women } \\
\text { Positive for HPV (\%) }\end{array}$ \\
\hline $\begin{array}{c}\text { Age of the patient } \\
\text { (years) }\end{array}$ & 16 & $8(50 \%)$ \\
\hline$<30$ & 14 & $4(28.5 \%)$ \\
\hline $30-40$ & 20 & $2(10 \%)$ \\
\hline$>40$ & & $9(64 \%)$ \\
\hline $\begin{array}{c}\text { Age at marriage } \\
\text { (years) }\end{array}$ & 14 & $5(16.7 \%)$ \\
\hline $18-25$ & 30 & $0(0 \%)$ \\
\hline $26-30$ & 6 & \\
\hline $31-35$ & Table 4. Distribution of Patients According to Various \\
Demographic Features
\end{tabular}

\begin{tabular}{|c|c|c|}
\hline Risk Factor & $\begin{array}{c}\text { Total No. of } \\
\text { Females }\end{array}$ & $\begin{array}{c}\text { No. of Women Positive } \\
\text { for HPV (\%) }\end{array}$ \\
\hline Para 1 & 11 & $1(9 \%)$ \\
\hline Para 2 & 25 & $5(20 \%)$ \\
\hline Para 3 & 14 & $8(57 \%)$ \\
\hline $\begin{array}{c}\text { Single sexual } \\
\text { partners }\end{array}$ & 48 & $12(25 \%)$ \\
\hline $\begin{array}{c}\text { Multiple sexual } \\
\text { partners }\end{array}$ & 2 & $2(100 \%)$ \\
\hline Condom & 24 & $1(4.1 \%)$ \\
\hline OCPs & 9 & $7(77.8 \%)$ \\
\hline Cu T & 6 & $3(50 \%)$ \\
\hline Coitus Interruptus & 6 & $1(16.7 \%)$ \\
\hline Tubectomy & 5 & $2(40 \%)$ \\
\hline $\begin{array}{c}\text { Table 5. Distribution of Patients According to Various } \\
\text { Risk Factors Associated with HPV }\end{array}$ \\
\hline \multicolumn{2}{|c}{}
\end{tabular}




\section{DISCUSSION}

Cervical cancer is one of leading cause of sufferings of the female population as of now. Virtually all cervical cancers are caused by human papilloma virus (HPV) infection. A regular screening programme for the detection of HPV is capable of reducing the incidence of invasive cervical cancer. Our study showed that the prevalence of HPV in women with abnormal cytology was $28 \%$ (Table 3). Villiers et $\mathrm{al}^{6}$ \& Rasu M et $\mathrm{al}^{7}$ demonstrated a prevalence of $35 \%$, which is in accordance with our present study. In many studies, younger age was found to be associated with HPV infection. Asiaf A et al ${ }^{8}$ found the highest prevalence of HPV infection in women below 30 years. Our study showed $57 \%$ positivity in the age group of $<30$ years. HPV is a sexually transmitted disease, and younger people are more engaged in sexual activities, so prevalence of HPV is more in the younger age group. In many studies, early age at marriage and early age at first coitus (Vinodhini $\mathrm{K}$ et al, ${ }^{9}$ Asiaf $A$ et $\mathrm{al}^{8}$ ) were found to be significant risk factors for HPV infection. In a study conducted by R Aggarwal et al 10 in 2006 , out of the total positive patients, $77 \%$ had marriage in the age between 16-25 years which is in accordance with our study, in which out of the total positive patients $64 \%$ had marriage in the age between 18-25 years. Significant relationship between increased parity and HPV infection was demonstrated by Vinodhini $\mathrm{K}$ et al. ${ }^{9}$ Our study showed that out of total positive cases, $57 \%$ were of para 3 . Furthermore, it has been shown that the transformation zone remains on the ectocervix for longer in multiparous women and thereby facilitates direct exposure to HPV and potential cofactors. ${ }^{11}$

In our study, we also tried to find the association between use of different contraceptives and HPV infection. It has been shown that use of OCPs were associated with HPV infection as out of total positive cases, $50 \%$ were using OCPs and $7 \%$ were using condoms. Remschmid et al ${ }^{12}$ in 2103 , in his study showed that $70 \%$ of patients having HPV were using OCPs as a contraceptive method. Similarly, a study by Victor Moreno et al in $2002^{13}$ concluded that longterm use of oral contraceptives could be a cofactor that increases risk of cervical carcinoma by up to four-fold in women who are positive for HPV infection. In vitro studies suggest that hormones might have a permissive effect for the growth of cervical cancer, by promoting cell proliferation and thus allowing cells to be vulnerable to mutations. In addition, oestrogen acts as an anti-apoptotic agent permitting proliferation of cells infected with oncogenic HPV. It has been reported that steroid hormones found in oral contraceptives may affect the HPV genome and increase viral expression of oncoproteins E6 and E7.14

\section{CONCLUSION}

Our study emphasised on the various risk factors associated with Human papillomavirus along with its prevalence that can lead to carcinoma cervix in high-risk women. Our study concluded that younger age at marriage, multiple sexual partners, multiparity, use of OCPs are the most important risk factors for the acquisition of HPV infection. Barrier protection during sexual intercourse has been demonstrated to decrease the incidence of HPV infection.

\section{REFERENCES}

[1] Bosch FX, Manos MM, Murioz N, et al. Prevalence of human papillomavirus in cervical cancer: a worldwide perspective. International biological study on cervical cancer (IBSCC) study group. J Natl Cancer Inst 1995;87(11):796-802.

[2] McLaughlin-Drubin ME, Munger K. Oncogenic activities of human papillomaviruses. Virus Res 2009;143(2):195-208.

[3] Villa LL, Franco EL. Epidemiologic correlates of cervical neoplasia and risk of human papillomavirus infection in asymptomatic women in Brazil. J Natl Cancer Inst 1989;81(5):332-40.

[4] Azocar J, Abad SM, Acosta H, et al. Prevalence of cervical dysplasia and HPV infection according to sexual behavior. Int J Cancer 1990;45(4):622-5.

[5] Jeronimo J, Bansil P, Lim J, et al. A multicountry evaluation of care HPV testing, visual inspection with acetic acid, and Papanicolaou testing for the detection of cervical cancer. Int J Gynecol Cancer 2014;24(3):576-85.

[6] De Villiers EM, Schneider A, Miklaw H, et al. Human papillomavirus infections in women with and without abnormal cervical cytology. The Lancet 1987;330(8561):703-6.

[7] Rassu M, Bertoloni G, Mengoli C, et al. HPV genotype prevalence in cervical specimens with abnormal cytology: a report from north east Italy. Scand J Infect Dis 2005;37(6-7):476-81.

[8] Asiaf A, Ahmad ST, Zargar MA, et al. Prevalence of human papillomavirus infection in a Kashmiri ethnic female population. Genet Test Mol Biomarkers 2012;16(8):904-9.

[9] Vinodhini K, Shanmughapriya S, Das BC, et al. Prevalence and risk factors of HPV infection among women from various provinces of the world. Arch Gynecol Obstet 2012;285(3):771-7.

[10] Aggarwal R, Gupta S, Nijhawan R, et al. Prevalence of high-risk human papillomavirus infections in women with benign cervical cytology: a hospital based study from North India. Indian J Cancer 2006;43(3):110-6.

[11] Autier P, Coibion M, Huet F, et al. Transformation zone location and intraepithelial neoplasia of the cervix uteri. Br J Cancer 1996;74(3):488-90.

[12] Remschmidt C, Kaufmann AM, Hagemann I, et al. Risk factors for cervical human papillomavirus infection and high-grade intraepithelial lesion in women aged 20 to 31 years in Germany. Int J Gynecol Cancer 2013;23(3):519-26.

[13] Moreno V, Bosch FX, Murioz N, et al. Effect of oral contraceptives on risk of cervical cancer in women with human papillomavirus infection: the IARC multicentric case-control study. Lancet 2002;359(9312):1085-92.

[14] Forslund O, Antonsson A, Higgins G, et al. Nucleotide sequence and phylogenetic classification of candidate human papilloma virus type 92. Virology 2003;312(2):255-60. 